Instructions for authors, subscriptions and further details:

\title{
Doing Good in the Neighborhood? The Effect of Coethnic Concentration on the Educational Attainment of Mexican, Filipino, and Vietnamese Children of Immigrants
}

Rennie Lee ${ }^{1}$

1) University of Melbourne, Australia

Date of publication: October $25^{\text {th }}, 2016$

Edition period: October 2016-February 2017

To cite this article: Lee, R. (2016). Doing Good in the Neighborhood? The Effect of Coethnic Concentration on the Educational Attainment of Mexican, Filipino, and Vietnamese Children of Immigrants. International Journal of Sociology of Education, 5(3), 214-243. doi: 10.17583/rise.2016.2176

To link this article: http://dx.doi.org/10.17583/rise.2016.2176

\section{PLEASE SCROLL DOWN FOR ARTICLE}

The terms and conditions of use are related to the Open Journal System and to Creative Commons Attribution License (CC-BY) 


\section{Doing Good in the Neighborhood? The Effect of Coethnic Concentration on}

\section{the Educational Attainment of}

\section{Mexican, Filipino, and Vietnamese Children of Immigrants}

Rennie Lee

University of Melbourne

(Received: 12 July 2016; Accepted: 18 August 2016; Published: 25 October 2016)

\section{Abstract}

An enduring puzzle in social science literature is that immigrants' children belonging to Asian subgroups consistently outperform their Latino counterparts even after parents' socioeconomic background is considered. These disparities may be explained by differences in the coethnic community. Using the Children of Immigrants Longitudinal Data in California, this study quantitatively examines whether living with more coethnics affects the educational attainment of Mexican, Vietnamese, and Filipino children of immigrants. The results indicate that Vietnamese children benefit from living with a higher number of coethnics but Mexicans and Filipinos do not. The enduring Vietnamese effect may be attributed to underlying social characteristics of the Vietnamese community, such as their refugee status or norms about success. Overall, the effect of coethnic neighbors on education depends on immigrants' aggregate characteristics.

Keywords: immigrants' children, coethnic community, educational attainment 


\section{¿Lo Están Haciendo Bien en el Barrio? El Efecto de la Concentración del Mismo Grupo Étnico en los Logros Educativos de los Hijos de Inmigrantes Mexicanos, Filipinos, y Vietnamitas}

Rennie Lee

University of Melbourne

(Recibido: 17 Julio 2016; Aceptado: 18 Agosto 2016; Publicado: 25

Octubre 2016)

\section{Resumen}

Un rompecabezas constante en la literatura de la inmigración es que los hijos de inmigrantes pertenecientes a los subgrupos asiáticos superan constantemente a sus homólogos latinos, incluso después de que los antecedentes socioeconómicos de los padres son considerados. Estas disparidades pueden explicarse por las diferencias en la comunidad de la misma etnia. Usando el Children of Immigrants Longitudinal Data en California, este trabajo examina si viviendo con más compañeros de su grupo étnico afecta el logro educativo de los hijos de los inmigrantes mexicanos, vietnamitas, y filipinos. Los resultados indican que los vietnamitas se benefician de vivir con un mayor número de compañeros de su grupo étnico, pero los mexicanos y filipinos no lo hacen. En los vietnamitas, el efecto persistente puede ser atribuido a las características sociales subyacentes de su comunidad, tales como su condición de refugiado o de su estrecha definición de éxito. Por lo tanto, ya sea que vivan con los vecinos del mismo grupo étnico tiene un efecto positivo o negativo sobre el logro educativo depende de las características de los inmigrantes.

Palabras clave: hijos de inmigrantes, comunidad del mismo grupo étnico, logro educativo. 
Trigrants' children from Asian and Latino subgroups represent 20 percent of school age children in the US and are an important focus of educational studies. One concern is that the two groups experience diverging educational trajectories and children from Asian subgroups consistently outperform their Latino counterparts. What is more perplexing is that these achievement differences persist net of parents' socioeconomic background. One reason for these disparities may be due to differences in the coethnic communities where immigrants' children reside. This study examines whether living in larger coethnic communities affects the educational attainment of Mexican, Vietnamese, and Filipino children of immigrants.

Understanding how ethnic group membership affects education has emphasized the role of cultural versus structural factors (Zhou \& Kim, 2006). This approach can be limited though; for instance, studies focusing on cultural arguments, repertoires, and networks among Asians and Latinos can overlook structural differences between the two groups, such as education levels, resources, and migration into the US (Bean, Brown, \& Bachmeier, 2015). Thus, it would be ideal to examine cultural and structural factors together, but this is rarely done because of data constraints, especially with quantitative methods. In turn, the goal of this paper is to begin to fill that gap by examining the coethnic community, which includes cultural and structural features, among three national origin groups with different structural characteristics.

\section{Neighborhood Effects: Coethnic Neighbors}

Aggregate effects at different levels are widely known to affect individual outcomes (e.g., neighborhood effects). One instance of this is coethnic concentration - the extent to which immigrants or their children live closely with people from the same country of birth, or coethnics. Often, coethnic concentration is calculated as the percentage of coethnics living in a small geographic area, such as a census tract. Coethnic concentration affects the children of immigrants' educational attainment (Portes \& Rumbaut, 2001; Portes \& Zhou, 1993), though its effect can be positive (Åslund, Edin, Fredriksson, \& Grönqvist, 2011) or negative (Bygren \& Szulkin, 2010; Grönqvist, 2006; Nielsen, Rosholm, Smith, \& Husted, 2003; Perreira, 


\section{Harris, \& Lee, 2006).}

Three hypotheses offer predictions about the effect of coethnic concentration on the children of immigrants' educational attainment: spatial segregation hypothesis, ethnic enclave hypothesis, and immigrants' characteristics hypothesis. However, the three hypotheses have not been examined together or considered with individual, family, school, and neighborhood characteristics. Bygren and Szulkin (2010) and Fleischmann et al. (2011) considered the spatial segregation and ethnic enclave hypotheses together on the children of immigrants' educational attainment and academic performance. Borjas (1995); Feliciano (2005); and Kroneberg (2008) considered the immigrants' characteristics perspective on the children of immigrants' educational attainment and academic performance, but the three hypotheses have not been considered together. Additionally, Pong and Hao (2007) examined individual, family, school, and neighborhood factors together on the children of immigrants' education, but did not examine the effect of the number of coethnic neighbors or the three hypotheses per se. This paper assesses the effect of the number of coethnic neighbors on the children of immigrants' educational attainment, net of individual, family, school, and neighborhood characteristics.

\section{Spatial Segregation Hypothesis}

The spatial segregation hypothesis posits that the concentration of coethnic neighbors has a negative effect on educational outcomes (Marston \& Van Valey, 1979; Massey, 1990; Massey \& Mullan, 1984; Musterd, 2005). Although the spatial segregation hypothesis did not frame its predictions in terms of coethnics per se, it can be thought of as such because spatial segregation refers to the isolation of social groups, such as racial and ethnic minorities or immigrant groups, from the majority population of the host society (Marston \& Van Valey, 1979; Massey \& Mullan, 1984; White, 1983). Most applications of spatial segregation include some measure of the share of social groups residing within a geographic area, such as the proportion of minorities, immigrant groups, or coethnics in a neighborhood (Åslund et al. 2011; Bygren and Szulkin 2010; Cutler and Glaeser 1997; White 1983).

Spatial segregation posits that living in neighborhoods with a high 


\section{Lee - Effect of Coethnic Concentration}

concentration of coethnic adults is unfavorable for education. Residents are isolated from well-informed and educated host society members, which lowers participation in mainstream institutions and impedes educational attainment (review in Alba, Logan, \& Crowder, 1997; cf. Esser, 2004; review in Marston \& Van Valey, 1979; Warner \& Srole, 1945). Neighborhoods with many coethnics are marginalized areas with social problems (Burgess, 1925; review in Bygren \& Szulkin, 2010), few resources, and limited mobility, delaying educational attainment for the next generations (Massey, 1990). Thus, the spatial segregation hypothesis views neighborhoods with large percentages of coethnics as uniformly negative.

The spatial segregation hypothesis is most commonly assessed with racial and ethnic minorities and immigrants (Cutler \& Glaeser, 1997; Massey, 1990; Massey \& Mullan, 1984), but its predictions have been extended to consider the children of immigrants' educational outcomes (Bygren \& Szulkin, 2010). The closest assessment of the spatial segregation hypothesis on the children of immigrants' education is by Bygren and Szulkin (2010), who found that children living with more coethnic adults had lower academic achievement. Although they focused on academic performance, their finding supports spatial segregation's hypothesis that a greater percentage of coethnic neighbors leads to lower education.

\section{Ethnic Enclave Hypothesis}

A second hypothesis, the ethnic enclave hypothesis, views living with coethnics as positively influencing educational outcomes (Zhou \& Bankston, 1998). This hypothesis was originally developed to explain immigrants' economic outcomes. Immigrants living with more coethnics attained higher wages than those in the primary labor market by relying on coethnic networks for job opportunities and training (Portes, 1998; Portes \& Zhou, 1992). The ethnic enclave hypothesis has been extended to consider the children of immigrants' academic outcomes (Åslund et al., 2011; Fleischmann et al., 2011; Perreira et al., 2006; Portes, 2000; Zhou \& Bankston, 1998). Immigrants' children benefit from coethnic assistance based on a shared national origin identity (Portes, 1998). Adult coethnics are concerned about children's well-being because of their shared national origin with immigrant parents. Parents rely on coethnic adult neighbors to 
monitor children's behavior, which discourages deviant behavior and encourage academic achievement (Pong \& Hao, 2007; Portes \& Rumbaut, 2001; Zhou \& Bankston, 1998). Thus, the ethnic enclave hypothesis suggests that living with a larger percentage of coethnics is uniformly positive.

When the ethnic enclave hypothesis has been assessed quantitatively, the results have been inconclusive. In the closest assessment of the ethnic enclave hypothesis on the children of immigrants' education, Åslund et al. (2011) found that a larger share of coethnic neighbors was positively associated with children's academic achievement. Although they focused on academic performance, their finding supports the ethnic enclave's hypothesis that a larger percentage of coethnic neighbors would lead to greater educational attainment. However, Kroneberg (2008) found no relationship between the extent of coethnic assistance and academic performance.

\section{Immigrants' Characteristics Hypothesis}

A third perspective, the immigrants' characteristics hypothesis, posits that the effect of the number of coethnic neighbors on educational attainment is contingent on immigrants' social, economic, and demographic characteristics (Borjas, 1992; 1995; Kroneberg, 2008; Portes \& Rumbaut, 2001). Immigrants' characteristics have been framed at several levels, such as individual immigrants or immigrant groups. Nonetheless, it makes no difference that these characteristics may occur at different levels because the premise of the immigrants' characteristics hypothesis is that there is no inherent benefit or detriment to living with coethnic neighbors. The effect of coethnic neighbors depends on immigrants' overall characteristics.

Immigrant group characteristics are the aggregate characteristics of people from the same country of origin (Feliciano, 2005; 2006). For instance, persons born in Vietnam living in the US belong to the same national origin group and share similar group characteristics, such as the average education of all Vietnamese in the US. Three group characteristics can influence the effect of the number of coethnic neighbors on the children of immigrants' educational attainment: average SES, educational selectivity, and classification by the US government. The relationship between each 
group characteristic, the number of coethnic neighbors, and educational attainment can be conceptualized as an interaction effect (cf. Borjas, 1995), although it has not always been done so.

One group characteristic, immigrant group SES in the destination country (occupation, education, and/or income) may have an interactive effect; the effect of the number of coethnic neighbors on education differs by group SES (cf. Borjas, 1995; cf. Kroneberg, 2008). When high SES groups live closely in a neighborhood, the effect of the number of coethnic neighbors on education is positive because there are more educated and skilled coethnics to illustrate the benefits of education, set high aspirations, and serve as educational resources (Borjas, 1992; 1995; Kroneberg, 2008). When low SES groups live closely, the effect of the number of coethnic neighbors on education is negative because there are more uneducated and low-skilled coethnics with fewer resources (review in Feliciano, 2005; cf. Zhou \& Kim, 2006).

Another group characteristic, an immigrant group's selectivity, may also have an interactive effect on the effect of the number of coethnic neighbors on educational attainment. Immigrant selectivity is the difference between those who migrate (immigrants) and those who remain in the origin country (non-migrants). Migrants can be selective on several dimensions, such as education or health. Highly selective migrants are of higher class status relative to non-migrants in the home country and often maintain their view of being high status in the destination county (Feliciano, 2006). When highly selective groups live closely in a neighborhood, the effect of the number of coethnic neighbors on education is positive because there are more educated coethnics to instill high educational expectations (Feliciano, 2006; Gibson, 1988; Zhou \& Kim, 2006). When less selective groups live closely, the effect of the number of coethnics on education is negative because there are more poorly educated coethnics with lower expectations (Feliciano, 2006; Zhou \& Kim, 2006).

Another group characteristic, the US government's classification of a group - such as unauthorized, legal, and refugees/asylees - may have an interactive effect on the effect of the number of coethnic neighbors on education (Banskton, 2014; cf. Portes \& Rumbaut, 2001; cf. Portes \& Zhou, 1993). Groups classified as unauthorized - such as Mexicans, Salvadorans, and Guatemalans-reside in the US without government permission, 
experience exclusionary state policies denying legal status, face limited opportunities, and have weak coethnic networks (Abrego, 2006; Portes \& Rumbaut, 2006). When unauthorized migrants live closely together, the effect of the number of coethnics on education is negative because there are more coethnics with limited resources and opportunities.

Immigrant groups entering the country legally, such as Filipinos, Indians, and Chinese, are permitted to stay and experience neutral government policies (Abrego, 2006; Portes \& Rumbaut, 2006). Legal immigrants, particularly high SES immigrants, can transfer their skills or invest in their local neighborhoods (Zhou, Tseng, \& Kim, 2009). When legal migrants live closely together, the effect of the number of coethnics on education is positive because of the greater number of coethnics with resources.

Refugees and asylees - such as the Vietnamese, Laotians, and Cambodians - have legal status and the right to work in the US. Refugees receive generous resettlement assistance and qualify for welfare provisions (Portes \& Rumbaut, 2006; Zhou, 2001; Zhou \& Bankston, 1998). When refugees live closely together, the effect of the number of coethnic neighbors on education is positive because there are more well-supported coethnics.

In the closest assessment of the immigrants' characteristics hypothesis on the children of immigrants' education, Kroneberg (2008) found that children with immigrant parents that primarily socialized with low SES coethnics had lower test scores than children with immigrant parents that socialized with high SES coethnics. Although Kroneberg (2008) focused on coethnics in the same metropolitan area rather than neighborhoods, his findings support the predictions of the immigrants' characteristics hypothesis that the effect of the number of coethnic neighbors on education depends on immigrants' overall characteristics.

\section{Case Studies: Mexican, Filipinos, and Vietnamese}

Mexicans, Filipinos, and Vietnamese are the three largest immigrant groups in San Diego, but have different aggregate characteristics, such as socioeconomic status, educational selectivity, and classification by the US government. The comparative cases allow us to a.) assess the extent to which these differences in group characteristics account for educational differences by national origin group; and b.) assess how a group's structural 


\section{Lee - Effect of Coethnic Concentration}

characteristics affect the relationship between coethnic neighbors and educational attainment.

Mexican immigrants have the lowest group SES and are the least selective of the three (Feliciano, 2005). Many work as unskilled/semi-skilled laborers with limited mobility (Abrego, 2006). Their classification by the US government includes unauthorized legal status, temporarily legal, and permanently legal though many have unauthorized legal status (Abrego, 2006; Portes \& Rumbaut, 2006).

In contrast, Filipinos are the most selective and have high education, income, and occupational statuses (Feliciano, 2005). They typically enter the US legally and the majority are skilled workers and professionals (Portes \& Rumbaut, 2006). Vietnamese immigrants have a low SES in the US but are highly educated relative to non-migrants in Vietnam (Feliciano, 2005). Their occupations in the US range from unskilled/semi-skilled laborers to entrepreneurs and are classified as refugees by the US government (Portes \& Rumbaut, 2006).

Table 1.

Predicted Effects of Coethnic Concentration on the Children of Immigrants' Educational Attainment

$\begin{array}{lll}\text { Spatial Segregation } & \text { Ethnic } & \text { Immigrants' } \\ \text { Hypothesis } & \text { Enclave } & \text { Characteristics } \\ & \text { Hypothesis } & \text { Hypothesis }\end{array}$

\begin{tabular}{llll}
\hline$\%$ Filipino & - & + & + \\
$\%$ & - & + & + \\
Vietnamese & & + & - \\
$\%$ Mexican & - & & + \\
Filipino & & + \\
Vietnamese & & - \\
Mexican & & \\
\hline
\end{tabular}




\section{Hypotheses}

Above, the predictions for the three hypotheses - the spatial segregation hypothesis, ethnic enclave hypothesis, and immigrants' characteristics hypothesis - are stated in the abstract. From the general hypotheses, I derive specific hypotheses about the relationship between coethnic neighbors and educational attainment for Mexicans, Filipinos, and the Vietnamese, and summarize them in Table 1.

The spatial segregation hypothesis posits that the number of coethnic neighbors negatively affects the educational attainment of Filipino, Mexican, and Vietnamese children because living with more coethnics is uniformly negative for all groups. The ethnic enclave hypothesis posits that the number of coethnics positively affects the educational attainment of Filipino, Mexican, and Vietnamese children because living with more coethnics is uniformly positive for all groups. The immigrants' characteristics hypothesis posits that the effect of the number of coethnic neighbors depends on immigrants' characteristics and differs by group. Filipino children living with more Filipinos will have a positive effect on educational attainment because of their high SES characteristics whereas Mexican children living with more coethnics will have a negative effect on educational attainment because of their low SES characteristics. Vietnamese children living with more coethnics will positively affect education because of their mostly positive and mixed SES characteristics.

According to the immigrants' characteristics hypothesis, when immigrants' characteristics are explicitly measured, the effect of the number of coethnic neighbors on education will disappear because there is no inherent benefit or detriment about coethnic residence. Any benefit or detriment is an effect of immigrants' underlying social characteristics. Nonetheless, it may not be possible to measure all the levels of immigrants' characteristics influencing education, but to the extent that it is possible, the effect of coethnic neighbors will disappear.

\section{Neighborhood, School, and Individual/Family Controls}

The effect of coethnic concentration on educational attainment must be examined net of neighborhood (neighborhood SES); school (school safety); 


\section{Lee - Effect of Coethnic Concentration}

family (parental SES, parental college expectations); and individual (sex, college aspirations, standardized math test scores) controls. While this list is not exhaustive, I include the most well-known factors predicting educational attainment (Kao \& Thompson, 2003).

First, the characteristics of the neighborhoods that children live in may influence their educational attainment. Neighborhood characteristics refer to the characteristics of all adults living in a small geographic area and include indicators, such as the average education or income (SES) of all adults in the neighborhood. Neighborhood SES positively affects educational attainment because neighborhood adults are role models and shape children's aspirations (Pong \& Hao, 2007). Adults in high SES neighborhoods are more likely to be high SES themselves and have more resources and information than adults in low SES neighborhoods (Pong \& Hao, 2007; Portes \& Zhou, 1993).

Second, school context also affects educational attainment. One indicator of school context is school safety, which measures the school's learning environment and can account for some differences in school quality or resources (Gronna \& Chin-Chance, 1999; Parcel \& Dufur, 2001). Schools with more social problems negatively affect education because children may feel more distracted and less attached to the school (review in Gronna \& Chin-Chance, 1999). Thus, children that perceive their school to be unsafe will attain lower education levels than children who perceive their school to be safer (Crosnoe, 2005).

Third, family background, such as parental education and income and parental expectations may influence educational attainment. Higher SES parents have greater resources and can exhibit the benefits of education to children (Portes \& Rumbaut, 2001). Thus, children with higher SES parents will attain higher educational levels. Additionally, parents with higher expectations motivate children and shape their orientation toward future goals (Kao, 1995; Vartanian, Karen, Buck, \& Cadge, 2007). Children with higher parental expectations will attain higher education levels than children with lower parental expectations.

Fourth, individual factors, such as gender, test scores, and educational aspirations, also influence education. Females are more likely to attain higher education levels than males and this has been well-documented among immigrants' children (Feliciano \& Rumbaut, 2005; Kao \& Tienda, 
1995) and native-borns (review in Buchmann, DiPrete, \& McDaniel, 2008). Educational aspirations, may also positively affect educational attainment because they capture goals or future ambitions (Feliciano, 2006; Perreira et al., 2006). Thus, children with higher educational aspirations will attain greater education levels than children with lower educational aspirations. Additionally, standardized test scores positively affect educational attainment because they are markers of individual achievement, learned information, or innate ability (review in Kao \& Thompson, 2003). Children with higher test scores will attain higher educational levels than children with lower test scores.

\section{Methodology}

This study analyzes data from the California portion of the Children of Immigrants' Longitudinal Study (CILS) in San Diego and Miami. I analyze the San Diego portion because it includes 1990 Census tract data on the social and economic characteristics of children's neighborhoods whereas the Miami data does not. This data is a nonrandom sample. Respondents are clustered by schools, which I adjust for with robust clustering in the regression analyses. In the first wave (1991), students were 14-15 and surveyed and interviewed from 17 schools in San Diego County. Students were re-interviewed in 1994 when they were 17-18 and from 2001-2003 when respondents were 24-25 (Feliciano \& Rumbaut, 2005). This study focuses on a sample of 1,132 Mexican, Filipino, and Vietnamese children with at least one foreign-born parent. Respondents were included in the sample based on their mother's country of birth. Foreign-born children are considered first generation and native-born children are considered second generation (Portes \& Rumbaut, 2001).

Although the third wave of data re-interviewed approximately 73 percent of the original sample, sample attrition remains a concern (Feliciano \& Rumbaut, 2005). Multiple imputation was performed on all independent variables with missing cases. Missing data on the dependent variable was not imputed ${ }^{1}$.

The ideal data set would include a large sample of immigrants' children from multiple national origins with information on family, school, and neighborhood characteristics (Conger, Schwartz, \& Stiefel, 2011). To my 
knowledge, this data does not exist. CILS comes the closest by offering a moderate sample of immigrants' children and information on their educational attainment, school context, and neighborhoods at the tract level. Although CILS does not include more extensive school and neighborhood information, such as school SES and the SES characteristics of coethnic neighbors, CILS remains more advantageous than other data. For instance, the National Longitudinal Survey of Youth (NLSY) does not include information on school context and has a small sample of first and second generation respondents. The National Education Longitudinal Survey (NELS), High School and Beyond (HS\&B), and High School Longitudinal Study (HSL) do not include tract level information. National Longitudinal Study of Adolescent to Adult Health (Add Health) has a large sample of immigrants' children and includes contextual variables at the census tract (e.g., proportion of racial groups). However, there is limited information by national origin and a small Asian sample, which is a large focus of this study. Thus, CILS is better suited for this study.

\section{Variables and Measures}

\section{Educational attainment}

The dependent variable is an individual's highest education in the third wave, measured as an ordinal variable with three categories: less than high school, high school graduate, and college graduate or higher.

\section{Coethnic neighborhood concentration}

The key independent variables are the percent of one's own coethnics living in the neighborhood, examined using three interactions between percent coethnic and national origin for Filipinos, Vietnamese, and Mexicans. Neighborhoods are measured by census tracts, which have an average size of 4,000 people and are intended to represent neighborhoods (Iceland \& Steinmetz, 2003). I calculated the percentage of Mexicans, Vietnamese, and Filipinos living in each tract by matching 1990 Census summary statistics to the tracts that respondents resided in 1991.

\section{Neighborhood SES}

Neighborhood SES is created using two 1990 US Census tract level 
variables-percent of homeownership and total income-which were standardized, summed together, and then averaged. Neighborhood SES ranges from 0 to 1; a higher value represents a higher SES neighborhood.

\section{School safety}

The school safety index is a 4-point standardized scale and a higher score represents a safer school (Portes \& Rumbaut, 2001). School safety is included to capture school resources or SES, which is not available in CILS.

\section{Individual variables}

Parental SES is a standardized unit weighted sum comprised of father and mother's education, occupational status, and home ownership in 1992. This variable ranges from -2.00 to +2.00 and is statistically well-behaved and more reliable than when measured independently (Portes \& Rumbaut, 2001). Parent's college expectations is a dichotomous variable of whether parents expect their children to attend college.

Individual achievement indicators include a respondent's percentile on standardized math tests in 1991. A higher percentile indicates a higher score. ${ }^{2}$ Educational aspirations is a dichotomous variable measuring aspirations for a college degree or more versus less than a college degree. Generation status was omitted because there is little variation between the $1.5,1.75$, and second generations.

\section{Results}

Table 2 presents the bivariate statistics for Mexicans, Filipinos, and Vietnamese, based on the complete imputed data set. There is a clear gap in educational mobility - approximately 27 percent of Filipino students and 41 percent of Vietnamese students are college graduates compared with 9 percent of Mexicans. The lower levels of college graduation among Filipinos is surprising as they have the highest parental and neighborhood SES. Mexicans and Filipinos live in neighborhoods with more coethnics than the Vietnamese. Overall, Table 2 indicates that educational attainment is not perfectly correlated with parental, neighborhood, and group SES. 
Table 2.

Bivariate Statistics of Mexican, Vietnamese, and Filipino. Children of Immigrants in San Diego, 1992-2003

\begin{tabular}{|c|c|c|c|}
\hline & Mexicans & Filipinos & Vietnamese \\
\hline \multicolumn{4}{|l|}{ Dependent Variable } \\
\hline \multicolumn{4}{|l|}{ Educational Attainment } \\
\hline HS Dropout & 9.0 & 2.0 & 4.2 \\
\hline HS Graduate & 82.5 & 70.8 & 54.5 \\
\hline College+ & 8.5 & 27.3 & 41.3 \\
\hline \multicolumn{4}{|l|}{ Neighborhood Characteristics } \\
\hline Mean \% of coethnics in neighborhood & 34.7 & 25.7 & 5.7 \\
\hline Min $\%$ of coethnics in neighborhood & 2.4 & 0 & 0 \\
\hline Max \% of coethnics in neighborhood & 90.0 & 75.7 & 14.9 \\
\hline Neighborhood SES & 0.3 & 0.5 & 0.4 \\
\hline \multicolumn{4}{|l|}{ School Characteristics } \\
\hline Safety Index & 2.6 & 2.5 & 2.4 \\
\hline \multicolumn{4}{|l|}{ Parental Characteristics } \\
\hline Parental SES & -0.6 & 0.3 & -0.3 \\
\hline \multicolumn{4}{|l|}{ Parental Expectations } \\
\hline$<$ College & 45.8 & 8.8 & 11.6 \\
\hline College+ & 54.2 & 91.2 & 88.4 \\
\hline \multicolumn{4}{|l|}{ Individual Characteristics } \\
\hline \multicolumn{4}{|l|}{ Sex } \\
\hline Female & 54.8 & 52.0 & 50.3 \\
\hline Male & 45.2 & 48.0 & 49.7 \\
\hline \multicolumn{4}{|l|}{ Age } \\
\hline 13 & 22.2 & 23.4 & 23.3 \\
\hline 14 & 45.8 & 47.8 & 38.6 \\
\hline 15 & 26.5 & 26.2 & 34.4 \\
\hline 16 & 5.6 & 2.7 & 3.7 \\
\hline \multicolumn{4}{|l|}{ Generation } \\
\hline 2nd generation & 64.6 & 57.5 & 19.6 \\
\hline 1st generation & 35.5 & 42.5 & 80.4 \\
\hline \multicolumn{4}{|l|}{ Standardized math scores } \\
\hline Bottom quartile (0-24\%) & 42.6 & 12.0 & 13.2 \\
\hline 2nd quartile (25-49\%) & 29.9 & 22.0 & 18.5 \\
\hline 3rd quartile (50-74\%) & 17.5 & 28.3 & 26.5 \\
\hline Top quartile (75-99\%) & 10.1 & 37.7 & 41.8 \\
\hline \multicolumn{4}{|l|}{ Aspirations } \\
\hline$<$ College & 22.5 & 4.1 & 4.2 \\
\hline College+ & 77.5 & 95.9 & 95.8 \\
\hline $\mathrm{N}$ & 378 & 565 & 189 \\
\hline
\end{tabular}




\section{Analytic Strategy}

This study uses ordinal logistic regression analysis, which requires that the assumption of parallel lines is not violated. To test this, I assessed Table 3 using proportional odds (coefficients do not vary between cut points) and non-proportional odds (coefficients vary between cut points) using generalized logistic regression models. Generalized logistic regression models are less restrictive than proportional odds models estimated by ordinal logistic regression but more parsimonious and interpretable than models estimated by multinomial logistic regression (Williams, 2005). I ran the full model using non-parallel odds and parallel odds and conducted likelihood ratio tests of the two models for each imputed data set. The likelihood ratio tests were not statistically significant, indicating no difference between models estimated with proportional odds and nonproportional odds. Therefore, I estimate my models using proportional odds because the non-proportional odds model did not significantly improve the model's fit.

I also analyzed these models using multilevel regression but they were not superior to ordinal logistic regression models with clustered standard errors. Thus, I use the latter, which makes fewer assumptions than multilevel models (Primo, Jacobsmeier, \& Milyo, 2007). 
Table 3

Odds Ratios Predicting Educational Attainment for Mexican, Filipino, and Vietnamese Children of Immigrants

\begin{tabular}{|c|c|c|c|c|c|}
\hline & Model 1 & Model 2 & Model 3 & Model 4 & Model 5 \\
\hline$\%$ Vietnamese in census tract & 0.977 & $0.930 * * *$ & 0.985 & 0,973 & $0.941+$ \\
\hline$\%$ Mexican in census tract & $0.986^{*}$ & $0.983 * *$ & 0.997 & $0.985^{* *}$ & 0.997 \\
\hline$\%$ Filipino in census tract & $1.009 * *$ & $1.006^{*}$ & $1.009 * *$ & $1.026+$ & 1.002 \\
\hline Vietnamese & $2.216 * * *$ & 1.457 & $2.735 * * *$ & & 1.487 \\
\hline Mexican & $0.401 * * *$ & $0.353 * * *$ & $0.490 * *$ & $0.226 * * *$ & 0.910 \\
\hline Filipino & & & & $0.492 * *$ & \\
\hline Interaction: & & & & & \\
\hline$\%$ Vietnamese*Vietnamese & & $1.100 *$ & & & $1.154 *$ \\
\hline Interaction: & & & & & \\
\hline$\%$ Mexican*Mexican & & & 0.987 & & \\
\hline Interaction: \%Filipino*Filipino & & & & 0.984 & \\
\hline Neighborhood SES & & & & & 1,664 \\
\hline School safety & & & & & $1.301 * *$ \\
\hline Parent's SES & & & & & $1.633 * * *$ \\
\hline Parent's College Expectations & & & & & $1.818^{*}$ \\
\hline College aspirations & & & & & $2.461 * *$ \\
\hline Math Scores & & & & & $1.952 * * *$ \\
\hline Male & & & & & $0.552 * * *$ \\
\hline
\end{tabular}

Table 3 presents the odds ratios of obtaining less than a high school degree, a high school degree, or a college degree, estimated by ordinal logistic regression. The odds ratios give the odds that are associated with a unit change in the independent variable of being in a lower outcome category of the dependent variable compared to a higher outcome category.

Table 3, Model 1 presents the separate effects of belonging to a particular national origin group and the ethnic composition of the neighborhood on the educational attainment of Mexican, Filipino, and Vietnamese children. I include national origin and the ethnic composition of the neighborhood to assess the aggregate ethnic effect on education without considering the specific characteristics of each national origin group. Model 1 is synonymous to ethnographic studies of neighborhoods that cannot disaggregate national origin effects with specific characteristics. Model 1 includes four variables: percent Filipino, Mexican, and Vietnamese in a neighborhood and national origin group. 
In Table 3, Model 1, the odds ratio for the percent of Filipinos living in a neighborhood is 1.009 and significant. For a one-unit increase in the percent of Filipinos in a neighborhood, the odds of being in a higher educational attainment category are 0.9 percent higher than being in a lower educational category, net of controls. ${ }^{3}$ Therefore, for one-unit increase in percent Filipino, the odds of obtaining a college degree is 0.9 percent higher than the odds of combined high school degree and less than a high school degree. Furthermore, the odds of combined college degree and high school degree is 0.9 percent higher than the odds of obtaining less than a high school degree. The odds ratio for the percent of Mexicans living in a neighborhood is 0.987 and statistically significant. The odds ratio for the percent of Vietnamese living in a neighborhood is not statistically significant.

I also include a categorical variable for national origin: Mexican, Vietnamese, and Filipinos as the reference group. The odds ratio for Mexican is 0.401 and significant, indicating that the odds of obtaining a higher education level are lower for Mexicans relative to Filipinos. The odds ratio for being Vietnamese is 2.216 and significant, suggesting that the odds of obtaining a higher education level are higher for Vietnamese compared with Filipinos.

Thus, Model 1 shows that national origin effects on education reflect aggregate group characteristics. Mexicans have lower odds of educational attainment whereas Vietnamese have higher odds. Similarly, the effects of ethnic neighbors also reflect aggregate group characteristics. Living with a higher percentage of Filipino neighbors is associated with higher education levels whereas living with a higher percentage of Mexican neighbors is associated with lower education levels.

Table 3, Models 2-4 provide a detailed look of living in neighborhoods with one's own coethnics by assessing the effect of the percentage of coethnic neighbors on educational attainment. Including an interaction between the percent of one's own coethnics in the neighborhood and national origin assesses a true coethnic effect on educational attainment. The interactions are analyzed separately in Models 2, 3, and 4 for the Vietnamese, Mexicans, and Filipinos, respectively. Modeling the interactions separately is easier to interpret because an interaction term changes the interpretation of the coefficient and no longer corresponds to a change in odds ratio. 


\section{Lee - Effect of Coethnic Concentration}

Model 2 includes an interaction between percent Vietnamese in a neighborhood and Vietnamese national origin to assess the effect of living with a higher percentage of Vietnamese coethnics on the educational attainment of Vietnamese children. There are three variables to consider in the interaction: percent Vietnamese neighbors, Vietnamese national origin, and the interaction term between percent Vietnamese neighbors and Vietnamese national origin. The odds ratio for percent Vietnamese is 0.93 and significant. This represents the odds ratio of being in a higher educational attainment category for one-unit increase in the percent of Vietnamese neighbors for Filipino children. To calculate the corresponding odds for Vietnamese children, I multiply the odds ratio for the percent of Vietnamese neighbors by the odds ratio of the interaction term $\left(0.93^{*} 1.1=1.023\right)$. For one-unit increase in the percent of Vietnamese neighbors, the odds of being in the college attainment category are 2.3 percent greater than the odds of being in the high school and less than high school categories, for Vietnamese children.

The odds ratio for Vietnamese national origin is 1.457 and not significant. The odds ratio for the interaction term is 1.1 and significant. The interaction term suggests that the percent of Vietnamese neighbors on educational attainment has a stronger, positive effect on educational attainment for Vietnamese children compared with Filipino children.

Overall, Model 2 shows that for Vietnamese children, living with a higher percentage of coethnics increases the odds of educational attainment. Additionally, the positive effect of living with coethnics on educational attainment is stronger for Vietnamese children, which suggests that the positive effect of coethnic neighbors is unique to Vietnamese children.

Models 3 and 4 assess the interactions between the percent of coethnic neighbors and national origin on educational attainment for Mexicans and Filipinos respectively. Both were not significant. In separate analyses, I analyzed Models 3 and 4 with all control variables and the interaction terms remained not significant.

Model 5 adds neighborhood, school, family, and individual variables to Model 2 to assess whether the Vietnamese interaction remains significant, net of controls. ${ }^{2}$ Model 5 also examines specific reasons that account for the aggregate national origin effects shown in Models 1-4. Model 5 shows that the odds ratios for percent Filipino and Mexican in a neighborhood and 
Mexican national origin are no longer significant, net of controls. The odds ratio for percent Vietnamese in the neighborhood borders significance, net of controls. There is no change in the odds ratio for Vietnamese national origin and the interaction term from Model 2. The odds ratios for school safety, parent's SES, parent's college expectations, college aspirations, math scores, and gender are significant and work in the predicted direction. Model 5 shows that net of controls, the interaction between the percentage of Vietnamese neighbors and Vietnamese national origin remains significant, but the positive effect associated with Filipino neighbors and the negative effects associated with Mexican neighbors and Mexican national origin are explained by socioeconomic factors.

\section{Discussion}

This study assesses the effect of the number of coethnic neighbors on the children of immigrants' educational attainment. Three frameworks offer predictions about the effect of the number of coethnics on educational outcomes: the spatial segregation hypothesis, the ethnic enclave hypothesis, and the immigrants' characteristics hypothesis. This study systematically tests all three perspectives for Mexican, Filipino, and Vietnamese children.

\section{Assessing the Spatial Segregation Hypothesis}

The spatial segregation hypothesis posits that living with more coethnics negatively affects educational attainment because children are isolated from educated and informed host society members (review in Marston \& Van Valey, 1979; Warner \& Srole, 1945). Thus, the effect of the number of coethnic neighbors is uniformly negative for all groups. My findings do not support spatial segregation's hypothesis because living with a higher percentage of coethnics has a positive effect for Vietnamese children and no effect for Mexican and Filipino children. Thus, the effect of the number of coethnic neighbors on educational attainment is not uniformly negative. My findings differ from Bygren and Szulkin (2010) who found that living with more coethnic neighbors was negatively associated with the children of immigrants' educational attainment. One reason is because they aggregated children's educational attainment from various national origin groups, which 


\section{Lee - Effect of Coethnic Concentration}

may conceal group differences. Thus, the negative association between coethnic neighbors and education could reflect the experience of some immigrant groups rather than an intrinsically negative effect of coethnic neighbors.

\section{Assessing the Ethnic Enclave Hypothesis}

The ethnic enclave hypothesis posits that living with more coethnics positively affects education because coethnic adults supervise and monitor children's behavior, which discourages deviant behavior and promotes school success (Zhou \& Bankston, 1998). Thus, the effect of the number of coethnic neighbors is uniformly positive for all groups. My results show that Vietnamese children living with more coethnics attain higher education levels, but there is no significant effect of living with more coethnics among Mexicans and Filipinos. In contrast to the ethnic enclave hypothesis, immigrants' children do not benefit educationally merely by living with more coethnics.

My results differ from Åslund et al. (2011) and Zhou and Bankston (1998), who found that coethnic concentration had a positive effect on academic performance and educational attainment. One reason is because both studies focused on the children of refugees so it is unclear how applicable their findings are for non-refugees. Thus, the positive association between coethnic neighbors and education could be related to refugee neighbors rather than an intrinsically positive effect of coethnic neighbors.

\section{Assessing the Immigrants' Characteristics Hypothesis}

The immigrants' characteristics hypothesis posits that the effect of the number of coethnic neighbors on educational attainment is contingent on immigrants' characteristics at different levels (Borjas, 1992; 1995; Feliciano, 2005; 2006; Portes \& Rumbaut, 2001). Although I cannot directly examine immigrant group characteristics, I examine Mexicans, Filipinos, and Vietnamese, who differ on group SES, educational selectivity, and classification by the US government. The immigrants' characteristics hypothesis posits that the effect of the number of coethnic neighbors will be 
negative for Mexican children's education because of their low SES characteristics. However, the effect of the number of coethnic neighbors will be positive for Filipino children's education because of their high SES characteristics and positive for Vietnamese children's education because their selectivity and government support alleviate their low SES. The immigrants' characteristics hypothesis posits that there is nothing inherently positive or negative associated with coethnic neighbors; rather, any positive or negative effect on education stems from immigrants' underlying social characteristics.

My results are consistent with Kroneberg (2008), who found that the socioeconomic composition of coethnics shaped children's test scores. This study extends Kroneberg's (2008) work by showing that immigrants' aggregate characteristics may be transmitted vis-à-vis neighborhoods where coethnics live together. While Kroneberg (2008) speaks of these processes more generally for immigrants' children without regard to national origin, this study illustrates the role of immigrants' aggregate characteristics for three groups with different characteristics.

My results support the immigrants' characteristics hypothesis in three ways. First, when the data is considered without controls, Mexican national origin is negatively associated with educational attainment and Vietnamese national origin is positively associated with educational attainment. This is consistent with the immigrants' characteristics hypothesis because the effect of national origin on education reflects aggregate group characteristics, which is positive for the Vietnamese and negative for Mexicans. This is consistent with Borjas (1992) and Feliciano (2005; 2006), who found that group characteristics, such as average income and educational selectivity, influenced the children of immigrants' education.

Second, my results show that without controls, Vietnamese children living with more coethnics are more likely to attain higher education. This supports the immigrants' characteristics hypothesis by showing that the positive effect of the number of coethnic neighbors on Vietnamese educational attainment is influenced by positive group characteristics. This is consistent with Borjas (1995) and Zhou and Kim (2006) who found a positive effect of the number of coethnic neighbors on educational attainment among higher SES (cf. Borjas, 1995) and more selective groups (cf. Zhou \& Kim, 2006). 


\section{Lee - Effect of Coethnic Concentration}

Third, my results show that net of socioeconomic controls, the percent of Filipino and Mexican neighbors and Mexican national origin have no effect on education whereas the percent of coethnic neighbors has a positive effect on Vietnamese children's education. Although I cannot explicitly measure group characteristics in my analyses, I include several factors to control for underlying socioeconomic characteristics of the immigrant group. When I include socioeconomic controls, the baseline negative Mexican effect and baseline positive Filipino effect disappear, suggesting that Mexican and Filipino national origin effects are explained by the low and high SES characteristics of Mexicans and Filipinos respectively. The remaining positive effect of Vietnamese coethnic neighbors indicates some residual effects of Vietnamese group characteristics that cannot be accounted for by SES factors alone. In the event that I could explicitly control for all group characteristics in my analysis and the immigrants' characteristics hypothesis is true, the positive effect of Vietnamese coethnic neighbors would disappear. The enduring effect of Vietnamese coethnic neighbors on Vietnamese children's educational attainment suggests some underlying characteristics of the Vietnamese that are not explicitly measured and included in my model.

Overall, my findings provide the most evidence for the immigrants' characteristics hypothesis and no support for the spatial segregation and ethnic enclave hypotheses. My results suggest that the education of immigrants' children is shaped by immigrants' individual and aggregate characteristics. Immigrants' characteristics can influence the effects of the number of coethnic neighbors on children's educational attainment. When immigrants' characteristics are positive, the number of coethnic neighbors will positively affect educational attainment. Consistent with the immigrants' characteristics hypothesis, the results imply that the effect of the number of coethnic neighbors is not intrinsically beneficial or detrimental, but depends on the underlying social characteristics of the immigrants. The immigrants' characteristics hypothesis offers the most comprehensive explanation of how the number of coethnic neighbors affects educational attainment by considering immigrants' characteristics at several levels.

One reason why coethnic residence has a significant and positive effect for Vietnamese children may be attributed to unmeasured characteristics of a tight-knit and well-established Vietnamese community in San Diego (Zhou, 
2001). Generous government support via Aid to Families with Dependent Children, Supplementary Security Income, and Refugee Cash Assistance, has ensured a basic level of well-being. Many pooled their resources from welfare assistance to start businesses or pay for children's college education (Rumbaut \& Ima, 1988; Zhou, 2001). The Vietnamese community in San Diego has coethnic community organizations directed at youths' education (Rumbaut \& Ima, 1988). Thus, despite their low SES, the resources in the Vietnamese community may explain why Vietnamese children benefit educationally from more coethnic neighbors.

Additionally, the Vietnamese community may have specific norms about success. Lee and Zhou (2015) found that Vietnamese immigrant parents defined success exclusively as attending a highly ranked university and a professional occupation. In turn, the specific definition of success is further reinforced by high-achieving coethnics and supplementary education programs in the Vietnamese community (Kasnitz, Mollenkopf, Waters, \& Holdaway, 2009). When high-achieving coethnic peers become the measure for success, Vietnamese children understand their own ethnic identity and educational expectations along similar lines. Thus, the educational benefit associated with Vietnamese neighbors may be attributed to both material resources and community norms of success.

\section{Conclusion}

This study's findings contribute to our understanding of the achievement gap between Asians and Latinos by highlighting the role of coethnic neighbors. Whether the effect of coethnic concentration is positive or negative differs by national origin group and depends on several features of immigrant groups, such as the level of government support and coethnic community norms. Future research may look further at how coethnic neighbors offer material and symbolic resources to benefit children's education.

This study suggests how coethnic communities reinforce the relationship between ethnicity and educational mobility. Children belonging to coethnic communities may internalize community-wide norms about education and attribute them to their ethnic background (Lee \& Zhou, 2015). These norms may reinforce the relationship between ethnicity and education in ways that individual and parental expectations do not because of the reference to 
coethnic peers as the benchmark for success. Overall, coethnic communities may contribute to our understanding of how educational achievement and disadvantage becomes ethnicized or racialized (review in Jiménez \& Horowitz, 2013; Lee \& Zhou, 2015).

Nonetheless, there are some limitations of this study. First, I do not have a measure of group characteristics, but use different groups as a proxy. I examine groups with different SES, educational selectivity, and government reception so they are useful as comparative cases. Future studies may examine how specific immigrant group characteristics shape education.

Second, the data is a non-representative sample of immigrants' children in San Diego. However, the Mexican, Filipino, and Vietnamese sample in the CILS is comparable to their national representation. In 2000, 30 percent of Mexicans and 87 percent of Filipinos had a high school degree or higher compared with 36 percent of Mexican immigrants and 91 percent of Filipino immigrants in CILS. In both the Census and CILS, 61 percent of Vietnamese immigrants had a high school degree or more.

Notwithstanding its limitations, my findings on Mexican, Filipino, and Vietnamese children may extend to other groups with similar characteristics. Poorly selected groups with low SES and a large population of unauthorized status - such as Salvadorans and Guatemalans - may show similar findings as Mexicans. Selective groups with high SES and skilled professionals, such as immigrants from Hong Kong and India, may resemble Filipinos. The Vietnamese in this study may resemble other refugee groups, such as Cambodians and Laotians, or highly selective groups with low SES, such as Colombians and Nicaraguans.

\section{Notes}

${ }^{1}$ I used Stata's ICE command (by Patrick Royston) to run Full Bayesian Multiple Imputation by Rubin (1987). I imputed missing cases on independent variables: school safety, parent's college expectations, and college aspirations. In total, 478 missing cases were imputed, changing the total sample size from 654 (Mexican=211; Vietnamese=149; Filipinos=294) to $1132 \quad$ (Mexican=378; Vietnamese $=189$; Filipinos $=565$ ).

${ }^{2}$ I also included standardized English test scores, but the two were highly correlated.

3 In separate analyses, I examined the neighborhood's racial composition (percent White, Black, Hispanic, and Asian) and found no significant effects. 


\section{References}

Abrego, L. J. (2006). I Can't Go to College Because I DonT Have Papers: Incorporation Patterns Of Latino Undocumented Youth. Latino Studies, 4(3), 212-231. doi:10.1057/palgrave.1st. 8600200

Alba, R. D., Logan, J. R., \& Crowder, K. (1997). White Ethnic Neighborhoods and Assimilation: The Greater New York Region, 19801990. Social Forces, 75(3), 883-912. doi: 10.1093/sf/75.3.883

Åslund, O., Edin, P.-A., Fredriksson, P., \& Grönqvist, H. (2011). Peers,

Neighborhoods, and Immigrant Student Achievement: Evidence from a

Placement Policy. American Economic Journal: Applied Economics, 3(2), 67-95. doi:10.1257/app.3.2.67

Banskton, C. L. I. (2014). Immigrant Networks and Social Capital. Polity Press.

Bean, F. D., Brown, S. K., \& Bachmeier, J. D. (2015). Parents Without Papers. Russell Sage Foundation.

Borjas, G. J. (1992). Ethnic Capital and Intergenerational Mobility. The Quarterly Journal of Economics, 107(1), 123-150. doi:10.2307/2118325

Borjas, G. J. (1995). Ethnicity, Neighborhoods, and Human-Capital Externalities. The American Economic Review, 85(3), 365-390.

Buchmann, C., DiPrete, T. A., \& McDaniel, A. (2008). Gender Inequalities in Education. Annual Review of Sociology, 34(1), 319-337. doi:10.1146/annurev.soc.34.040507.134719

Burgess, E. W. (1925). The Growth of the City: an Introduction to a Research Project. Ardent Media.

Bygren, M., \& Szulkin, R. (2010). Ethnic Environment During Childhood and the Educational Attainment of Immigrant Children in Sweden. Social Forces, 88(3), 1305-1329. doi:10.1353/sof.0.0298

Conger, D., Schwartz, A. E., \& Stiefel, L. (2011). The Effect of Immigrant Communities on Foreign-Born Student Achievement. International Migration Review, 45(3), 675-701. doi:10.1111/j.17477379.2011.00862.x

Crosnoe, R. (2005). Double Disadvantage or Signs of Resilience? The Elementary School Contexts of Children From Mexican Immigrant Families, 42(2), 269-303. doi:10.3102/00028312042002269 
Cutler, D. M., \& Glaeser, E. L. (1997). Are ghettos good or bad? The Quarterly Journal of Economics, 827-872.

Esser, H. (2004). Does the "New" Immigration Require a 'New' Theory of Intergenerational Integration?1. International Migration Review, 38(3), 1126-1159. doi:10.1111/j.1747-7379.2004.tb00231.x

Feliciano, C. (2005). Does Selective Migration Matter? Explaining Ethnic Disparities in Educational Attainment among Immigrants' Children. International Migration Review, 39(4), 841-871. doi: 10.1111/j.17477379.2005.tb00291.x

Feliciano, C. (2006). Beyond the Family: The Influence of Premigration Group Status on the Educational Expectations of Immigrants' Children. Sociology of Education, 79(4), 281-303. doi:10.1177/003804070607900401

Feliciano, C., \& Rumbaut, R. G. (2005). Gendered paths: Educational and occupational expectations and outcomes among adult children of immigrants. Ethnic and Racial Studies, 28(6), 1087-1118. doi:10.1080/01419870500224406

Fleischmann, F., Phalet, K., Neels, K., \& Deboosere, P. (2011). Contextualizing Ethnic Educational Inequality: The Role of Stability and Quality of Neighborhoods and Ethnic Density in Second-Generation Attainment. International Migration Review, 45(2), 386-425. doi:10.1111/j.1747-7379.2011.00852.x

Gibson, M. A. (1988). Accommodation without assimilation: Sikh immigrants in an American high school. Cornell University Press. doi:10.5860/CHOICE.26-2246

Gronna, S. S., \& Chin-Chance, S. A. (1999). Effects of School Safety and School Characteristics on Grade 8 Achievement: A Multilevel Analysis. Grönqvist, H. (2006). Ethnic Enclaves and the Attainments of Immigrant Children. European Sociological Review, 22(4), 369-382. doi:10.1093/esr/jc1002

Iceland, J., \& Steinmetz, E. (2003). The effects of using census block groups instead of census tracts when examining residential housing patterns. Bureau of the Census.

Jiménez, T. R., \& Horowitz, A. L. (2013). When White Is Just Alright: How Immigrants Redefine Achievement and Reconfigure the 
Ethnoracial Hierarchy. American Sociological Review, 78(5), 849-871. doi:10.1177/0003122413497012

Kao, G. (1995). Asian-Americans as model minorities? A look at their academic performance. American Journal of Education, 103(2), 121159.

Kao, G., \& Thompson, J. S. (2003). Racial and Ethnic Stratification in Educational Achievement and Attainment. Annual Review of Sociology, 29(1), 417-442. doi:10.1146/annurev.soc.29.010202.100019

Kao, G., \& Tienda, M. (1995). Optimism and Achievement. Social Science Quarterly, 76(1), 1-20.

Kasnitz, P., Mollenkopf, J. H., Waters, M. C., \& Holdaway, J. (2009). Inheriting the City. Harvard University Press. doi:10.7758/9781610446556

Kroneberg, C. (2008). Ethnic Communities and School Performance among the New Second Generation in the United States: Testing the Theory of Segmented Assimilation. The ANNALS of the American Academy, 620(1), 138-160. doi:10.1177/0002716208322714

Lee, J., \& Zhou, M. (2015). The Asian American Achievement Paradox. Russell Sage Foundation.

Marston, W. G., \& Van Valey, T. L. (1979). The Role of Residential Segregation in the Assimilation Process. The ANNALS of the American Academy, 441(1), 13-25. doi:10.1177/000271627944100103

Massey, D. S. (1990). American apartheid: Segregation and the making of the underclass. American Journal of Sociology, 96(2), 329-357.

Massey, D. S., \& Mullan, B. P. (1984). Processes of Hispanic and Black Spatial Assimilation. American Journal of Sociology, 89(4), 836-873. doi:10.2307/2779254

Musterd, S. (2005). Social and Ethnic Segregation in Europe: Levels, Causes, and Effects. Journal of Urban Affairs, 27(3), 331-348. doi:10.1111/j.0735-2166.2005.00239.x

Nielsen, H. S., Rosholm, M., Smith, N., \& Husted, L. (2003). The schoolto-work transition of 2 nd generation immigrants in Denmark. Journal of Population Economics, 16(4), 755-786. doi:10.1007/s00148-003-0164-Z 
Parcel, T. L., \& Dufur, M. J. (2001). Capital at Home and at School: Effects on Student Achievement. Social Forces, 79(3), 881-911. doi:10.1353/sof.2001.0021

Perreira, K. M., Harris, K. M., \& Lee, D. (2006). Making It in America: High School Completion by Immigrant and Native Youth. Demography, 43(3), 511-536. doi:10.1353/dem.2006.0026

Pong, S.-L., \& Hao, L. (2007). Neighborhood and School Factors in the School Performance of Immigrants' Children. International Migration Review, 41(1), 206-241. doi:10.1111/j.1747-7379.2007.00062.x

Portes, A. (1998). SOCIAL CAPITAL: Its Origins and Applications in Modern Sociology. Annual Review of Sociology, 24, 1-24.

Portes, A. (2000). The Two Meanings of Social Capital. Sociological Forum, 15(1), 1-12. doi:10.1023/A:1007537902813

Portes, A., \& Rumbaut, R. G. (2001). Legacies: The Story of the Immigrant Second Generation.

Portes, A., \& Rumbaut, R. G. (2006). Immigrant America. Berkeley and Los Angeles: University of California Press.

Portes, A., \& Zhou, M. (1992). Gaining the upper hand: Economic mobility among immigrant and domestic minorities. Ethnic and Racial Studies, 15(4), 491-522. doi:10.1080/01419870.1992.9993761

Portes, A., \& Zhou, M. (1993). The New Second Generation: Segmented Assimilation and its Variants. The ANNALS of the American Academy, 530(1), 74-96. doi:10.1177/0002716293530001006

Primo, D. M., Jacobsmeier, M. L., \& Milyo, J. (2007). Estimating the Impact of State Policies and Institutions with Mixed-Level Data. State Politics \& Policy Quarterly, 7(4), 446-459. doi:10.1177/153244000700700405

Rubin, D. B. (1987). Multiple Imputation for Nonresponse in Surveys. New York: John Wiley \& Sons.

Rumbaut, R. G., \& Ima, K. (1988). The Adaptation of Southeast Asian refugee youth: A compartive study. Washington D.C.: U.S. Office of Refugee Resettlement.

Vartanian, T. P., Karen, D., Buck, P. W., \& Cadge, W. (2007). Early factors leading to college graduation for asians and non-asians in the united states. The Sociological Quarterly, 48(2), 165-197. doi:10.1111/j.15338525.2007.00075.x 
Warner, W. L., \& Srole, L. (1945). The social systems of American ethnic groups.

White, M. J. (1983). The Measurement of Spatial Segregation. The American Journal of Sociology, 88(5), 1008-1018.

Williams, R. (2005). Gologit2: A Program for Generalized Logistic Regression/Partial Proportional Odds Models for Ordinal Dependent Variables. Retrieved August 17, 2016, from http://www.nd.edu/ rwilliam/stata/gologit2.pdf

Zhou, M. (2001). Straddling Different Worlds: The Acculturation of Vietnamese Refugee Children. In R. G. Rumbaut \& A. Portes (Eds.), Ethnicities: Children of Immigrants in America.

Zhou, M., \& Bankston, C. L., III. (1998). Growing up American: How Vietnamese Children Adapt to Life in the United States. Russell Sage Foundation.

Zhou, M., \& Kim, S. S. (2006). Community forces, social capital, and educational achievement: The case of supplementary education in the Chinese and Korean immigrant communities. Harvard Educational Review, 76(1), 1-29. doi:10.17763/haer.76.1.u08t548554882477

Zhou, M., Tseng, Y.-F., \& Kim, R. Y. (2009). Suburbanization and New Trends in Community Development. In Contemporary Chinese America.

Rennie Lee is Lecturer on Social and Political Sciences at the University of Melbourne

Contact Address: rennie.lee@unimelb.edu.au 